\title{
CORPORATE SOCIAL REPORTING DEVELOPMENT IN LITHUANIA
}

\author{
Lina Dagiliené $\dot{\mathbf{}}^{1}$ Šviesa Leitoniené⿱ \\ ${ }^{1}$ Kaunas University of Technology, Lithuania, lina.dagiliene@ ktu.lt \\ ${ }^{2}$ Kaunas University of Technology, Lithuania, sviesa.leitoniene@ktu.lt \\ cross ${ }^{\text {ref }}$ http://dx.doi.org/10.5755/j01.em.17.4.2982
}

\begin{abstract}
The paper analyses issues of corporate social reporting development in Lithuania. Social reporting issues are the logical part of social accounting approach which determines that companies should provide also non-financial information in order to satisfy the goals of stakeholders concerned. European countries, including Lithuania, are not formed a single system of corporate social reporting. Thus, not only a relatively small number of companies make these statements, but at the same time they are different in content and structure, and therefore not always comparable.

The objective of this paper is to investigate development of corporate social reporting in Lithuania. The research methods applied in this article are the analysis of legal acts, logical and comparative analysis of scientific literature, analysis of social reports.

The results of the paper showed that Lithuania takes place in social accounting and reporting: the determination of social objectives in the National Strategy for Sustainable Development, National Network of Responsible Business, belonging to socially responsible international organizations, educational seminars, studies about the social reporting in Lithuania. However, these changes are more scientific and educational nature, has little to do with the actual business activities.

Most problems of slow development are related to current inadequate legal framework for social accounting and reporting. They could be solved with the support of state institutions and professional organizations.

Keywords: corporate social reporting, social accounting.

JEL Classification: M40, M41.
\end{abstract}

\section{Introduction}

Large companies are driven to act ethically and socially in order to diminish negative effects of their activity. In order to gain more customers and the public trust, the companies are likely to reveal more positive about their social activities. So companies seek to create a positive image of their business. In the current business environment it is often not enough just to earn maximum profits. Growing competition in the market aims the companies to show not only a strong financial position, but also its social responsibility with their stakeholders. At the same time it is very difficult to assess the level of social activity due to the fact that usually social disclosure is voluntary and very heterogeneous. In this research it is guided by the concept of corporate social responsibility.

The main goal of social accounting and reporting is to create both social transparency system for responsible decision-making and company's communication with the groups concerned. Social reporting issues are the logical part of social accounting approach which determines that companies should provide also non-financial information in order to satisfy the goals of stakeholders concerned. Only a few Lithuanian researchers analysed social reporting problems in their papers: Dagiliene (2010), Dagiliene \& Bruneckiene (2011), Dagiliene \& Gokiene (2011), Leitoniene \& Sapkauskiene (2012). Empirical research related to the researches of social responsibility and social accounting in Lithuanian companies is sporadic and fragmented. The major part of research is of educative and incentive nature and has been initiated and implemented by national institutions: the study of the legal framework in the Republic of Lithuania regarding the factors that promote and impede corporate social responsibility (2007), the investigation "Social responsibility self-assessment guide for business" (2010). In these studies the focus is on socially responsible business idea, while lacking emphasizing social reporting importance as consequences of corporate social responsibility (CSR). Thus the research problem is raised by the question: what are the problems of corporate social reporting development in Lithuania?

The goal of this article is to investigate development of corporate social reporting in Lithuania.

The object of the article is corporate social reporting.

The research methods applied in the article are the analysis of legal acts, logical and comparative analysis of scientific literature, analysis of social reports. 


\section{Theoretical researches of corporate social reporting}

The European Union has established the social and economic model of the company, which accepts responsibility for stakeholder groups. This suggests that social factors are gaining meaning and significance of evaluating companies and their enabled products, the brand and its activities. Society draws attention to global problems caused by business entities, and the latter wishing to gain public recognition, publicly declare its policy of social responsibility.

The main source of information for corporate social responsibility (CSR) is a social reporting. Corporate social reporting is the performance monitoring and evaluation system, which is created to ensure compliance with company business environment, economy and society. To inform the public about the policies in this area, companies may provide various social responsibility (progress) reports, environmental protection reports, sustainable development reports, annual reports or simply publish social information on their websites. In general social responsibility report is a document of the company, which provides information about the company's planned and ongoing social and environmental performance, taking into account the results already achieved. In order to prepare such reports the specific social information must be available about the company's interaction with the environment, employees, community, customers and other stakeholders. While corporate social responsibility report varies and their approach to social responsibility, but in general they are prepared in accordance with the principles of the Global Compact, which includes human rights, improvement of relations with employees, the environment and fighting corruption.

Investigating corporate social reporting development in Lithuania, it is first necessary to start from a socially responsible business ideas spread. In Lithuania, like other EU countries, investigations are still concentrated on the promotion of CSR ideas (Ruzevicius \& Serafinas, 2007; Bernatonyte \& Simanaviciene, 2008, Juscius \& Snieska, 2008, Ruzevicius, 2008; Dagiliene, 2009; Amstromskiene \& Adamoniene, 2009, Juscius, 2009; Bernatonyte, Vilke \& Kaizeriene, 2009; Ruzevicius, 2009; Dagiliene \& Bruneckiene, 2010; Bagdoniene \& Paulaviciene, 2010; Simanskiene \& Pauzoliene, 2010; Simanaviciene, Kovaliov \& Subonyte, 2011; Dagiliene \& Gokiene , 2011; Leitoniene \& Sapkauskiene, 2012). Most of these economic investigations is designed for research and development tendencies of CSR Initiatives in Lithuania (Ruzevicius \& Serafinas, 2007; Amstromskiene \& Adamoniene, 2009; Bernatonyte, Vilke \& Kaizeriene, 2009, Juscius, 2009; Ruzevicius, 2009). Other investigations are designed for integration of social responsibility and organizations management systems (Bernatonyte \& Simanaviciene, 2008; Juscius \& Snieska, 2008; Bagdoniene \& Paulaviciene, 2010; Simanskiene \& Pauzoliene, 2010).

Some Lithuanian accounting researchers work focuses on the disclosure of social information (Vaskelienė \& Selepen, 2008, Legenzova, 2008; Dagiliene, 2009; Dagiliene \& Bruneckiene, 2010; Dagiliene \& Gokienè, 2011; Leitoniene \& Sapkauskiene, 2012). Political, social and cultural changes create the need to gather and analyze information about social and environmental factors, and determine the changes in traditional accounting systems. The first studies in this field analyzed only the additional information, its quality, quantity and presentation of financial statements (Vaskeliene \& Selepen, 2008, Legenzova, 2008; Dagiliene, 2009).

Only since 2010 studies started to raise the issue of social accounting and reporting (Table 1).

Table 1. The theoretical researches of social accounting and reporting in Lithuania

\begin{tabular}{|c|c|c|c|}
\hline $\begin{array}{c}\text { The } \\
\text { researcher }\end{array}$ & $\begin{array}{l}\text { Object of the } \\
\text { research }\end{array}$ & Aim of the research is: & Problems of social reporting \\
\hline $\begin{array}{l}\text { Dagiliene } \\
(2010)\end{array}$ & $\begin{array}{l}\text { Financial } \\
\text { statement }\end{array}$ & $\begin{array}{l}\text { to investigate the level of social information } \\
\text { disclosure in Lithuania. }\end{array}$ & $\begin{array}{l}\text { Legal acts and voluntary social } \\
\text { reporting }\end{array}$ \\
\hline $\begin{array}{l}\text { Dagiliene \& } \\
\text { Bruneckiene } \\
(2010)\end{array}$ & $\begin{array}{l}\text { Financial } \\
\text { statement and } \\
\text { website }\end{array}$ & $\begin{array}{l}\text { to investigate tendencies of the level of social } \\
\text { information disclosure in Lithuania. }\end{array}$ & $\begin{array}{l}\text { Legal acts and voluntary social } \\
\text { reporting }\end{array}$ \\
\hline $\begin{array}{l}\text { Dagiliene \& } \\
\text { Gokiene (2011) }\end{array}$ & $\begin{array}{l}\text { Social } \\
\text { responsibility } \\
\text { reports }\end{array}$ & $\begin{array}{l}\text { to investigate the valuation variables of social } \\
\text { responsibility reports and to analyze social } \\
\text { responsibility reports of Lithuanian companies. }\end{array}$ & $\begin{array}{l}\text { Legal acts, voluntary social } \\
\text { reporting, management systems } \\
\text { standards, legal options }\end{array}$ \\
\hline $\begin{array}{l}\text { Dagiliene } \\
\text { (2011) }\end{array}$ & $\begin{array}{l}\text { Social media } \\
\text { and website }\end{array}$ & $\begin{array}{l}\text { to investigate disclosure of social information in } \\
\text { social media and web sites of diary industry } \\
\text { companies. }\end{array}$ & Voluntary social reporting \\
\hline $\begin{array}{l}\text { Leitoniene \& } \\
\text { Sapkauskiene } \\
(2012)\end{array}$ & $\begin{array}{l}\text { Social } \\
\text { responsibility } \\
\text { reports }\end{array}$ & $\begin{array}{l}\text { carrying out theoretical analysis of social } \\
\text { accounting disclosure determinants and to identify } \\
\text { factors of social reporting by Lithuanian firms. }\end{array}$ & $\begin{array}{l}\text { Traditional accounting } \\
\text { principles and standards, legal } \\
\text { acts and voluntary social } \\
\text { reporting }\end{array}$ \\
\hline
\end{tabular}


Dagiliene (2010) conducted the research of social responsibility disclosure in annual reports. Dagiliene \& Bruneckiene (2010) analyzed the role of the voluntary disclosure aspect of CSR. Dagiliene \& Gokiene (2011) carried out the valuation of social responsibility reports of Lithuanian companies. Dagiliene (2011) investigated the social disclosure in social media and websites of Lithuanian dairy industry. The results of investigation showed that dairy industry's participation in social media is mainly focused on brand advertising. Issues relating to social responsibility about products, environment, human resources and community are disclosed only fragmentally in websites.

In 2012 Leitoniene \& Sapkauskiene also investigated issues of corporate social reporting. These studies distinguished that the basic problem of social accounting in Lithuania is the limitations of corporate social accounting regulation.

Lithuania takes place in social accounting and reporting: the consolidation of social objectives in the National Strategy for Sustainable Development, National Network of Responsible Business, belonging to socially responsible international organizations, educational seminars, study about the social responsibility of the situation in Lithuania preparation. However, these changes are more scientific and educational nature, has little to do with the actual business activities.

\section{Situation of corporate social reporting in Lithuania}

The legal presumption of CSR initiatives was created in Lithuania's accession to the EU period. In 200309-11 the Lithuanian Government approved the National Strategy for Sustainable Development. Under this strategy and other CSR initiatives in promoting the legal acts, Lithuanian companies on their willingness to assume additional responsibilities to improve business practices, introduce modern human resource management technologies, implements natural resource-efficient technologies, manufacturing processes used for human health-friendly materials, creating strategic business plans for possible negative effects of natural and social environment, harmonizing labour relations and actively participate in social dialogue.

The biggest voluntary initiative of CSR worldwide is Global Compact. Since 2005, there is the National Network of Responsible Business operating as part of the Global Compact initiative in Lithuania. Companies that joined the Global Compact, declare that they apply 10 principles of social responsibility, disclosing in annual social reports for stakeholders. Dissemination and promotion of CSR initiative in the network is expanding every year. According to the annual activity reports of the Lithuanian National Responsible Business Network this network comprises 57 companies and organizations in Lithuania in 2008, 61 - in 2009, 65 - in 2011. The fastest connection has already become apparent in 2011 the beginning of January to April when 10 new companies joined to the Network. Companies are removed from the National Network in the cases of interruption of business collaboration and the absence of obligatory social reports within a certain period. Lithuanian National Responsible Business Network had united 54 Lithuanian companies and 13 organizations on 1st of January, 2012.

Although the National Network in Lithuania is expanding, it was noted that members often delay in reporting or as whole does not: only 11 organizations (out of 57 members) present social responsibility reports in 2008, 12 organizations - in 2009, 16 - in 2010 and 21 - in 2011.

In response to found out abuses in companies reports of recent years, many countries have taken initiatives to review the accounting principles, in order to increase corporate transparency. Usually social reporting contains various issues that raise interest of stakeholders: human rights and human resources, product design and development, environmental protection, bribery and community. The Global Reporting Initiative (GRI) is one of the most popular non-governmental initiatives in the social and sustainable performance reporting and standardization and this methodology refers to reporting economic, social and environmental information based on corporate performance. However, despite of methodological discussions on this theme, social disclosure increases the transparency of the business. The major part of Lithuanian companies is oriented towards compulsory presentation of financial reports and financial information disclosure on requisition. It shows the lack of culture in understanding the real impact of socially responsible business. Thus the level of social reporting is low in Lithuanian companies. Without doubt, Lithuania has a relatively recent development of socially responsible business. So far, however, remains a socially responsible business is more incentive.

\section{Corporate social reporting development disincentives}

Legal acts. In Lithuania, like in many developing countries the promotion of business disclosure about its social activities started in state institutions and professional organizations in the initiative. Laws and 
regulations were adopted that encourage companies to submit compulsory financial information in the financial statements and annual reports. Law on Financial Statements of Entities (Article 25, paragraph 2) and Law on Consolidated Accounts of Entities (Article 9, paragraph 2) establish a mandatory rule only on financial disclosure, and companies that must prepare an annual report from the financial and non-financial performance analysis should present "the environmental and employee matters related information" (Table 2).

Table 2. Legislation and its impact on corporate social reporting - Law on Financial Statements of Entities 2001, as last amended on 2008

The law and its provisions affecting corporate social reporting

Legal acts influence on corporate social reporting

The law is relevant to CSR, as the financial statements are prepared in order to fairly present the company's assets, equity, liabilities, revenues and expenses. Such mandatory obligations on companies give clear guidance for companies.

Article 2, paragraph 2 provides that if general partnership, limited partnership or individual company, which are not under an obligation to draw up financial reports under this Law, take decision on the drawing up of financial reports at their own discretion, they must draw up the financial reports in compliance with the requirements set by this Law.

Article 4 provides the application of generally accepted accounting principles to the drawing up of financial reports.

Article 25, paragraph 1 states that public limited liability companies, private limited liability companies, general partnerships and limited partnerships all participants whereof are public limited liability companies or private limited liability companies must draw up the annual report in addition to annual financial reports.

And article 25, paragraph 2 (and article 9, paragraph 2 of Law on Consolidate Accounts of Entities 2001, as last amended on 2008) provides that annual reports must include analysis of financial and non-financial performance, information relating to environmental and employee matters.

These laws provided that generally accepted accounting principles should be applied to the financial statements. Traditional accounting principles and limitations of Business accounting standards is one of the main reasons for determining corporate decision not to disclose social information in traditional financial statements. The prevailing accounting theory developed over a long period of time, while social disclosure is a new area of accounting. For this reason, some existing generally accepted accounting principles and standards restrict the disclosure of social opportunities. The main objective of financial statements is to reflect a true and fair view of the state of the company and must include policies on social responsibility policy as well. However, such accounting principles as the implementation and viability of information comparability complicate the social information inclusion in mandatory reporting. Thus, the social demand for information requires major changes in traditional accounting models, but is now mandatory reporting principles limitations due to the fact that social information is provided only for voluntary reports.

Also, companies listed on the NASDAQ OMX Vilnius Stock Exchange must comply with the Code of Corporate Governance, which encourages companies to disclose information adequately for the market (Table 3). This document recommends that listed companies comply with certain standards of transparency and ensure the quality of management, to improve disclosure to shareholders, in order to increase confidence of investors and other stakeholder groups. The Code does not recommend specifically how and how much the company should provide information about social and environmental business risks. Although provisions of the Code of Corporate Governance for listed companies on the NASDAQ OMX Vilnius are much more specific than the mentioned above legal requirements, but these requirements are summarized in the form and may be treated differently. Thus, corporate social information is different in scope and quality. For this reason, in 2012 CSR guidelines have been developed, which aim is to help listed companies to apply social and environmental requirements of business and to increase the transparency of social reporting.

The state of legislation has provided a number of measures that could encourage companies to integrate CSR concept or specific measures in their activities. In addition, a number of measures are new, 
some of them have not even been started to apply (e.g. Implementation program of green procurement, companies' annual reports of environmental and personnel issues, etc.). This shows that companies lack information about how they can use their legal options.

Table 3. Legislation and its impact on corporate social reporting - The Corporate Governance Code for the Companies Listed on NASDAQ OMX Vilnius 2006, as last amended on 2009

\begin{tabular}{|c|c|}
\hline $\begin{array}{c}\text { The law and its provisions affecting corporate } \\
\text { social reporting }\end{array}$ & Legal acts influence on corporate social reporting \\
\hline \multicolumn{2}{|c|}{$\begin{array}{l}\text { The Code covers areas related to the protection of the interests of shareholders, an appropriate balance and } \\
\text { distribution of functions between the company's supervisory and management bodies, encourages companies to } \\
\text { adequately disclose the market. }\end{array}$} \\
\hline $\begin{array}{l}\text { Paragraph } 1.4 \text { states that a company supervisory and } \\
\text { management bodies should ensure that the rights and } \\
\text { interests of persons other than the company } \\
\text { shareholders (e.g. employee, creditors, suppliers, } \\
\text { clients, local community), participating in or } \\
\text { connected with the company's operation, are duly } \\
\text { respected. }\end{array}$ & $\begin{array}{l}\text { This paragraph promotes CSR disclosure, providing the } \\
\text { company's duty to respect the stakeholders, not just the } \\
\text { interests of shareholders. However, it must be noted that the } \\
\text { Code does not provide listed companies to improve their } \\
\text { performance reports so that investors, creditors could see their } \\
\text { environmental, social and related risks. }\end{array}$ \\
\hline $\begin{array}{l}\text { Paragraphs } 8.1,8.2,8.3,8.4,8.5 \text { states that } \\
\text { remuneration policy and procedures for approval, } \\
\text { revision and disclosure of directors' remuneration } \\
\text { established in the company should prevent potential } \\
\text { conflicts of interest and abuse in determining } \\
\text { remuneration of directors, in addition it should } \\
\text { ensure publicity and transparency both of company's } \\
\text { remuneration policy and remuneration of directors. }\end{array}$ & $\begin{array}{l}\text { The provisions on executive pay publication to promote CSR } \\
\text { in public. In order to maximize the company's remuneration } \\
\text { policy of transparency, the Code requires disclosure of } \\
\text { information about the income of each director individually. }\end{array}$ \\
\hline $\begin{array}{l}\text { Paragraphs } 9.1,9.2,9.3 \text { states that corporate } \\
\text { governance framework should recognize the rights } \\
\text { of stakeholders as established by law and encourage } \\
\text { active co-operation between companies and } \\
\text { stakeholders in creating the company value, jobs and } \\
\text { financial sustainability. For purposes of this } \\
\text { Principle, the concept "stakeholders" include } \\
\text { investors, employees, creditors, suppliers, clients, } \\
\text { local community and other persons having certain } \\
\text { interest in the company concerned. }\end{array}$ & $\begin{array}{l}\text { Paragraphs contribute to CSR disclosure, encouraging } \\
\text { businesses to comply with legislative requirements and ensure } \\
\text { the rights of stakeholders. It is also encouraged to disclose } \\
\text { information about the employer and the employee's } \\
\text { cooperation in the field of counseling staff. }\end{array}$ \\
\hline $\begin{array}{l}\text { Paragraph } 1.10 \text { provides list of minimum } \\
\text { information that should reveal the companies, but } \\
\text { companies are encouraged to go beyond the } \\
\text { information specified in this list. }\end{array}$ & $\begin{array}{l}\text { This paragraph shall encourage adequate, accurate and timely } \\
\text { disclosure of information about the company and contribute to } \\
\text { the company's transparency. It is questionable whether this } \\
\text { document can contribute significantly to the promotion of CSR } \\
\text { disclosure because it is a recommendatory nature. In addition, } \\
\text { provide only limited ways and means of information about the } \\
\text { corporate governance disclosure. Environmental and social } \\
\text { reporting for the company's perspective is not developed. } \\
\text { There is a lack of socially responsible corporate culture and } \\
\text { investment guidelines. }\end{array}$ \\
\hline
\end{tabular}

At present in Lithuania there is no one central source, where, under the "one-stop shop", you can get all the information about state institutions initiatives of socially responsible business development and promotion issues.

Voluntary social reporting. Compulsory social reporting for companies is specified in more than one European country. The European Commission has approved the EU Accounts Modernisation Directive Guide, which provides that a certain amount of the company must provide not only financial information but also information about the employees and the environment. It is likely that many countries will follow these recommendations. In Lithuania there also were attempts to make the social reporting compulsory by accepting the Law of Corporate Social Initiatives. This law is intended to only one area within the meaning of CSR, corporate social responsibility to employees and their family members. 
In Lithuania social disclosure is voluntary. Companies are not bound to prepare social responsibility, sustainable development or environmental reports and to include data of social responsibility in the annual financial statements. For this reason, the Lithuanian companies CSR disclosure content, scope and the sources are uneven and unstructured. Some Lithuanian companies prepare separate social responsibility reports (e.g. Swedbank AB, AB LESTO, former AB RST and VST, AB TEO LT); the other provide information on CSR activities in their annual reports (e.g. AB Achema group, AB ORLEN Lithuania "concern" MG Baltic "). In the report of corporate social responsibility at the national level progress in Lithuania 2008-2010 (prepared by the UNDP project "Gateway: Social and environmental innovation") the 100 largest Lithuanian companies' web sites provided information has been analysed. The results of investigation show that most of companies disclose information about their socially responsible activities. Some companies have a separate section of the CSR and the environment. In addition, Leitoniene \& Sapkauskiene (2012) investigated that in the 2006-2010 period, only three companies, one of which AB TEO LT has provided the annual social responsibility report; one company provided four reports since 2007 , four have submitted three social reports, while the remaining two or one.

The part of the social responsibility reports is prepared and publicized because some companies participate in the United Nations Global Compact network. The social responsibility reports of such companies (i.e. Communications on Progress) are prepared by the Global Compact principles. There is a space available in electronic reporting tool for the Lithuanian language. For example, Swedbank AB, UAB Medical bank, Ukio Bankas prepare their reports by the Global Compact 10 principles. But as shown in Leitoniene \& Sapkauskiene (2012) study social responsibility reports differ in the extent of social information and quality. The main reason for differences in social information is the scope and content of the individual sectors varied business specifics, stock listings, foreign investment and environmental pollution.

International guidelines for voluntary reporting partially solve this problem. GRI is the global set of voluntary guidelines for sustainable development reporting requirements. This initiative is designed to CSR reporting requirements of the application of a particular company, depending on the area. The main objective of GRI is to develop voluntary reporting rules that are applied on a global scale and to ensure the quality of the information, consistency and practical use. Sustainability reporting guidelines consist of principles and indicators that are used to measure the economic, environmental and corporate social progress. However, the GRI principles are criticized because they focus on the presentation of information about the environment, so there is no equilibrium between the three components of sustainable development. In addition, the United Nations Environment Program and Public Environmental Reporting Initiative interest in voluntary environmental reporting concepts. GRI methodology is not very popular in Lithuania. Only the mature companies (e.g. AB TEO LT, AB SEB Bank) use it.

Businesses and NGOs in partnership with the aim to promote socially responsible business principles in the following areas: environment, labour relations, business integration into society, corporate citizenship and volunteering in the promotion of human rights, corruption and corporate transparency. For instance, several members of the network have been participating in the initiative "Clear Wave" launched in 2007. This project focuses on broad public awareness campaign against payment of wages without taxes and introduction of the first label on transparency in Lithuania. The project aims to attract as many businesses to use the label of transparency in labour relations.

\section{Conclusions}

Analyzing development of corporate social reporting in Lithuanian companies, these main conclusions were made:

- Lithuania takes place in social accounting and reporting: the consolidation of social objectives in the National Strategy for Sustainable Development, National Network of Responsible Business, belonging to socially responsible international organizations, educational seminars, study about the social responsibility of the situation in Lithuania preparation. However, these changes are more scientific and educational nature, has little to do with the actual business activities. Still more declaratory socially responsible business ideas dominate in Lithuania.

- Lithuania participates in the international initiatives of responsible business. Lithuanian National Responsible Business Network had united 54 Lithuanian companies and 13 organizations on 1st of January, 2012.

- Lithuanian companies are faced with problems that hamper the development of corporate social reporting in Lithuania. Most problems are related to current inadequate legal framework for social accounting and 
reporting. They could be solved with the support of state institutions and professional organizations. These problems could be attributed to legal acts and traditional standards for accounting, limitations of regulation for mandatory and voluntary reporting, lack of application of legal options for social initiatives, the absence of single source for social information, promotion of business and NGO's partnership in social activities.

\section{References}

1. Analysis of the Republic of Lithuania the legal framework for the promoting and hindering factors of corporate social responsibility (2007). Source: http://www.socmin.lt/index.php?1998324661.

2. Astromskiene, A., \& Adamoniene, R. (2009). Tendencies of enterprise social responsibility initiatives in Lithuania. Economics and Management - 2009, 217-221.

3. Bagdoniene, D., \& Paulaviciene, E. (2010). The integration of social responsibility and organizations management system. Economics and Management - 2010, 366- 373.

4. Bernatonyte, D. \& Simanaviciene, Z. (2008). Cases study of corporate social responsibility in Lithuania business society. Business and Management, 501-505.

5. Bernatonyte, D., Vilke, R., \& Keizeriene, E. (2009). Economic crisis impact directions concerning corporate social responsibility in Lithuanian SME. Economics and Management - 2009, 229-234.

6. Corporate Governance Code for the Companies Listed on NASDAQ OMX Vilnius (2006). Source: http://www.nasdaqomxbaltic.com/files/vilnius/teisesaktai/The\%20Corporate\%20Governance\%20Code\%20for\%20t he\%20Companies\%20Listed\%20on\%20NASDAQ\%20OMX\%20Vilnius.pdf

7. Dagiliene, L. (2009). The role of voluntary disclosed information in financial valuation. Social Research, 17(3).

8. Dagiliene, L. (2010). The research of corporate social responsibility disclosures in annual reports. Engineering Economics, 21 (2), 197-204.

9. Dagiliene, L., \& Bruneckiene, J. (2010). The role of voluntary disclosure information in the context of social responsibility. Economics and Management -2010, 451-456.

10. Dagiliene, L., \& Gokiene, R. (2011). Valuation of corporate social responsibility reports. Economics and management -2011, 21-27.

11. Dagiliene, L (2011). Disclosure of social information in social media and websites: a case study of Lithuanian dairy industry. Znalosti pro tržni praxi 2011: nova generace pracovniku (Generace Y) = Knowledge for market use 2011: new generation of workers (Generation Y): sbornik z mezinarodni vedecke konference, Societas Scientiarum Olomucensis II. Olomouc, 72-78.

12. Global Reporting Initiative -GRI. Source: https://www.globalreporting.org/Pages/default.aspx.

13. Global Compact. Source: http://unglobalcompact.org/

14. Guidelines for Corporate Social Responsibility Stock Exchange listed companies: methodological tool to improve the responsibility of the ISA in 2012. Source: http://www.undp.lt/index.php?page=leidiniai\&hl

15. Juscius, V., (2009). Corporate social responsibility and corporate identity during contemporary economic crisis. Economics and Management - 2009, 264-269.

16. Juscius, V., \& Snieska, V. (2008). Influence of corporate social responsibility on competitive abilities of corporations'. Engineering Economics, 3, 34-44.

17. Leitoniene, S., \& Sapkauskiene, A. (2012). Analysis of social information as measure of ethical behaviour of Lithuanian firms. Economics and Management -2012, No.17(3).

18. Legenzova, R. (2008). Valuation of Lithuanian companies' ownership structure relationship with the financial information presentation. Economics and Management -2008, 48-54.

19. National Network of Responsible Business in Lithuania. Source: http://globalcompact.lt/lt/

20. Republic of Lithuania Law of Financial Statement Entities. Source: http://www3.lrs.lt/psl/inter3/dokpaieska.showdoc

21. Republic of Lithuania Law of Consolidate Accounts of Entities. Source: http://www3.lrs.lt/psl/inter3/dokpaieska.showdoc

22. Ruzevicius, J., \& Serafinas, D. (2007). The development of socially responsible business in Lithuania. Engineering Economics, 1, 36-43.

23. Ruzevicius, J. (2009). Development of sustainable and socially responsible business in Lithuanian the international context. Economics, 86, 68-75.

24. Simanaviciene, Z., Kovaliov, R., Subonyte, J. (2011). Corporate social responsibility SWOT analysis policy in Lithuania. Economics and Management-2011, 605-613.

25. Simanskiene, L., \& Pauzuoliene, J. (2010). Corporate social responsibility significant to Lithuanian organizations. Management theory and studies for rural business and infrastructure development, 20.

26. Vaskeliene, L., \& Selepen, J. (2008). Information about intellectual capital disclosure in Lithuanian joint stock companies. Economics and Management - 2008, 88-96. 